\title{
Annotations of First Generation Systems Development in Sweden
}

\author{
Janis Bubenko Jr. \\ Department of Computer and Systems Science, Royal Institute of Technology and Stockholm \\ University, Forum 100, SE-16440, Kista, Sweden \\ janis@dsv.su.se
}

\begin{abstract}
This work presents episodes of first generation information systems development in Sweden using two particular computers, ALWAC IIIE, during the period 1957-1961, and Univac III during 1963-1964. The ALWAC IIIE at ADB Institute, Gothenburg, was used for technical as well as for administrative applications. Another episode concerns re-engineering of an inventory management application; it used the ALWAC IIIE for the Swedish Defence Material Administration in 1960. The next episode concerns the computer Univac III. A sales contract between Götaverken $\mathrm{AB}$ and Univac included a guarantee by Univac to transfer one of Götaverken's punched card routines to a magnetic tape oriented routine on Univac III. The development work was carried out on a Univac III at Kantonalbank in Bern, Switzerland. They did the work in night shifts during a period of five months. Only one Univac III was installed in Sweden.
\end{abstract}

Keywords: First generation, information system development, Alwac IIIE, Univac III, Gothenburg.

\section{Introduction}

Information systems development is today a complex activity encompassing many types of activities and involving different kinds of stakeholders. It uses many different methods, techniques, and supporting tools. The development process deals with issues of many kinds such as organisational, economic, administrative, technical, social, as well as political. During the 1950-1960 decade, called the first generation of systems development, the development process was much simpler.

In the 1950s, heavy emphasis was on primarily two types of activities: programming and testing. Very little effort was allocated to business analysis, requirements gathering, and other "early activities" of the systems life-cycle (for a good survey see [7]). Normally, they programmed in a low-level "machine language" corresponding to the computer at hand. Therefore, systems development related closely to a particular brand of a computer. The problem- and system-analysis phases of the life cycle were not well developed. They did not use structured and formal system description techniques. These first started to appear in Sweden around the mid-to-late 1960s, when methods and techniques for this were developed in Sweden's first university department of information systems [6]. On the other hand, this did perhaps not matter so much as the routines processed by these early systems often were limited and well 
defined (by input-process-output descriptions and by flowcharts). Another, not often mentioned, trait of the first generation systems work was that it often implied "physically heavy" work. Input and output data as well as magnetic tapes required transportation to/from the computer centre; these media had a considerable weight, sometimes as much as 30-50 kilograms or more.

This article deals with first generation information systems development in Sweden using two particular computers, the ALWAC IIIE during the period 1957-1961 and the Univac III during 1963-1964. The author was closely involved with both these computers. Historically, this paper also gives an account of efforts to introduce and market two new computer brand names, ALWAC and UNIVAC, in Sweden in the late 1950s and in the early 1960s, respectively. Memories of ALWAC, presented here, complement well the history of ALWAC in Turku [9].

\section{The ALWAC IIIE Computer}

The industrialist Axel Wenner-Gren imported the ALWAC III E from the USA ${ }^{1}$ in 1957. His idea was to use the ALWAC IIIE as a basis for further developing computing know how in Sweden and eventually to start Sweden's own manufacturing of computers. The Swedish production of the ALWAC III E was renamed to Wegematic 1000. Later, they were to produce an enhanced ALWAC IIIE, named Wegematic 8000 , in the Nyman Factories in Bollmora in the southern part of Stockholm. The Wegematic 8000 never materialised. Incidentally, the name ALWAC is an acronym from "Axel Leonard Wenner-Gren Automatic Computer". special feature of ALWAC representing the E-register, an index register. An image of the ALWAC appears in Figure 1.

ALWAC III E was a drum-oriented computer. The drum had four "high-speed" 32-word channels with four read-write heads and 256 "slower" channels of 32 words each. A word consisted of 32 bits of data or two 16-bit instructions. An instruction had an operation code of 8 bits and an address field of 8 bits. The computer was not as fast as the Swedish BESK, or its follower the FACIT EDB, but it was slightly more "modern"; it had an index register suited for repeating operations, e.g. in matrix calculations. The input output capacity was low. For input, it used paper tape at a speed of a few hundred characters per minute or punched cards at a rate of about 100 cards per minute. Output operations, except tape, were very slow; written text appeared on a flexo-writer having a speed of less than an IBM electric typewriter, about 10 characters per second. The ALWAC III E in Sweden had no secondary storage such as tape stations or disks.

Electronically, the ALWAC IIIE had a vacuum tube design. The speed was about 200 instructions per second. Physically, the ALWAC IIIE was not as large as one remembers the Univac I or similar computers. It easily fit into a room of, say, 50 square meters. Of course, being a vacuum tube computer it needed cooling, normally through a double floor. Programming of the ALWAC IIIE was in pure machine code (see also Figure 3). They wrote programs in blocks of 32 words, or twice as many

\footnotetext{
${ }^{1}$ ALWAC Corporation, 13040 South Cerise Avenue, Hawthorne, California.

${ }^{2}$ Thanks to Tord-Jöran Hallberg for this information.
} 
instructions. A block constituted a drum channel. An executing program entered one of the four "high-speed" channels and execution started at some specified location. A typical instruction word could look like $8707573 \mathrm{~b}$, which contained two instructions

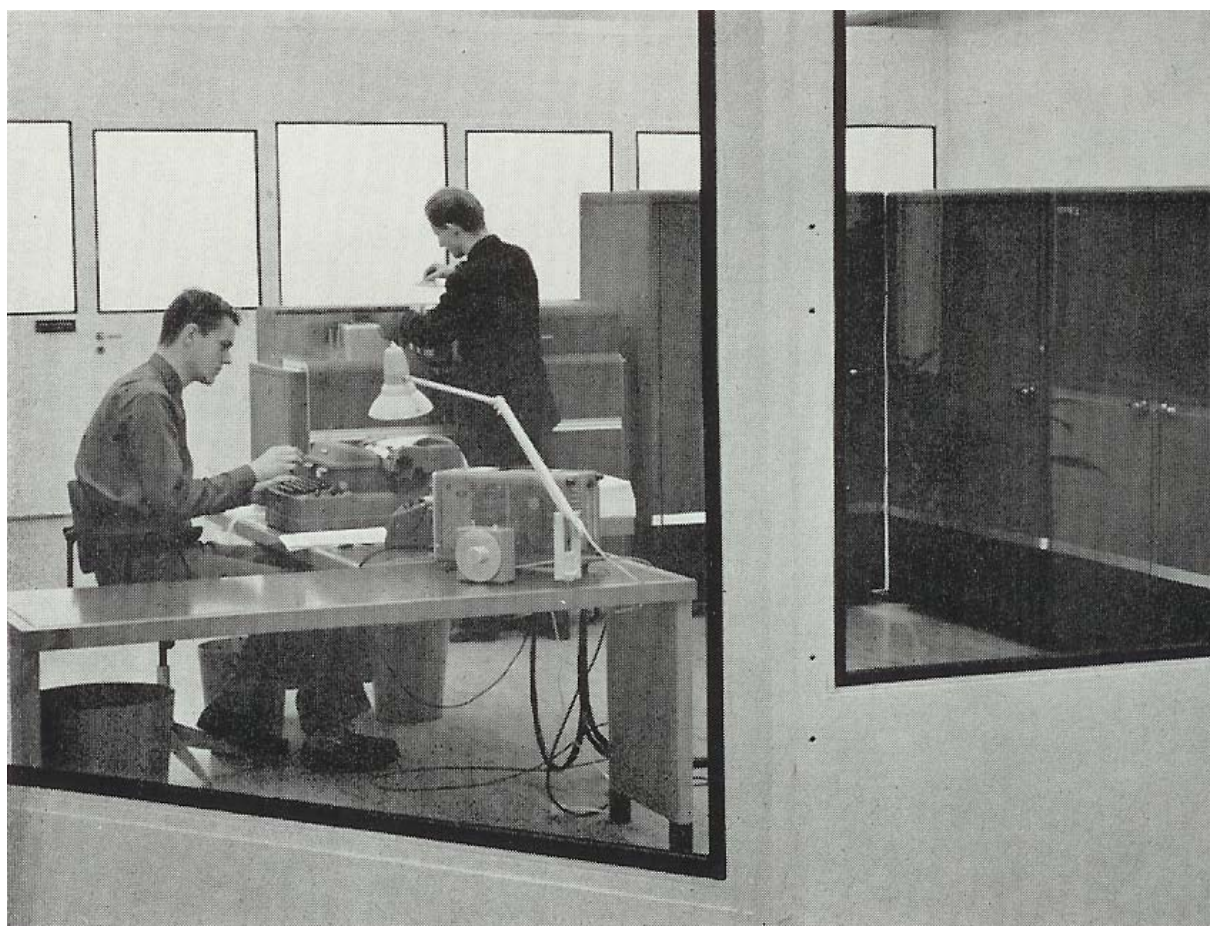

Fig. 1. The ALWAC IIIE installation at Chalmers

8707 : Copy the contents of drum channel 07 into high-speed channel 4

$573 \mathrm{~b} \quad$ : Bring the contents of cell $3 \mathrm{~b}$ into the index (E) register

The repertoire consisted of some 64 instruction types, including instructions for indexing, arithmetic, and reading and writing contents of drum channels into or out from the high speed channels. Our programs really looked like lists of eight hexadecimal digit phone numbers.

In the period from 1957 to 1961 about ten ALWAC IIIE or Wegematic 1000 computers were installed in Sweden, primarily in universities. See also appendixes in [9].

\subsection{ALWAC at Chalmers in Gothenburg}

The ALWAC IIIE was delivered to Chalmers in the summer of 1957 and gave the university a real "kick" in many topic areas. Personally, after the first programming course, the author started, together with Andrejs Grivans, to work on their master thesis topic, which concerned the buckling strength of arch bridges. Professor S.O. Asplund (head, Department of Structural Mechanics, School of Civil Engineering), who was a pioneer of computer usage at Chalmers, supervised us. A few years earlier, he 
had been using the BESK, the first Swedish computer located in Stockholm, for various stress calculations in structural mechanics. Other users of ALWAC IIIE were primarily researchers from departments belonging to the school of chemical engineering and researchers from departments within the school of electrical engineering. In addition, one frequently saw a few numerical analysts in the computer room.

An independent institute, the ADB-Institutet, initially led by Bertil Greko ${ }^{3}$, administered the ALWAC IIIE at Chalmers. Until its "death" in the early 1970s, the ALWAC IIIE resided on the Chalmers campus. The institute had initially a staff of about five to six persons, including two or three engineers. Later it developed into a selfsupporting organisation, by selling computer time to Chalmers and by doing consulting jobs and selling computer time over the western part of Sweden. The computer time "sold" to Chalmers was, I believe, extremely cheap as part of a deal between Chalmers and the ADB-Institute.

\subsection{Technical Systems Applications}

After 1958, I worked part time for a year in professor Asplund's consulting company (Autostatik AB). We developed programs for a wide range of calculations within the realm of structural mechanics [8]. Our efforts [1] in trying to sell these programs and services to engineering companies were not successful. The "market" was suspicious of "modern electronic gadgets" and preferred traditional, slide-rule calculations. The Swedish "market" was not yet ready to do business with us. However, only ten to fifteen years later the situation changed drastically. Many consulting companies in the field of engineering became heavy users of different kinds of software packages for engineering calculations, using their own computers or larger service centres. However, during the late 1950s it was not easy to do business by selling computational power to consulting companies.

\subsection{Administrative Systems Applications}

In 1958, the ADB-Institutet was, in fact, the major data consulting and service company in western Sweden ${ }^{4}$. It recruited young staff primarily from Chalmers, taught them programming, and gave them part-time, or hourly salaried jobs in developing programs and systems for business and industry in the western part of Sweden. Around 1957 the ADB-Institute also engaged in a managerial position Ingemar Dahlstrand, one of Sweden's first programming language scientists; he came from SAAB (Langefors' group) and in 1959 eventually moved to FACIT Electronics AB, EDB-centralen in Gothenburg, where he developed Sweden's first Algol compiler.

An active sales and marketing manager of the ADB-Institute was Sidney Werngren. Among other things he involved me in developing a program for inventory control and management of operations in a forestry industry, Forsviks Skogar, located some 250 kilometres north of Gothenburg [3]. This was a practically complicated system, primarily because data was "born" (captured) in the forest and the results of the computer run had to be delivered back $250 \mathrm{~km}$ away. We could not use ordinary

\footnotetext{
${ }^{3}$ Bertil Greko had a MBA from Stockholm School of Economics.

${ }^{4}$ Also FACIT started a computing center in Gothenburg at about 1959, using the FACIT EDB computer, a derivative of BESK.
} 
pencil and paper in the forest because of rain and wetness. Instead, we used plastic sheets and permanent ink pens to register data about the work performed. There was no telecommunication solution at that time. For some reason we did not use the "teleprinter" in this application, probably because the forestry had no staff that could punch a teleprinter tape and transmit the information to Gothenburg. As all administrative applications at this time, this one was also "batch-processing" oriented. It ran periodically, in this case once a month.

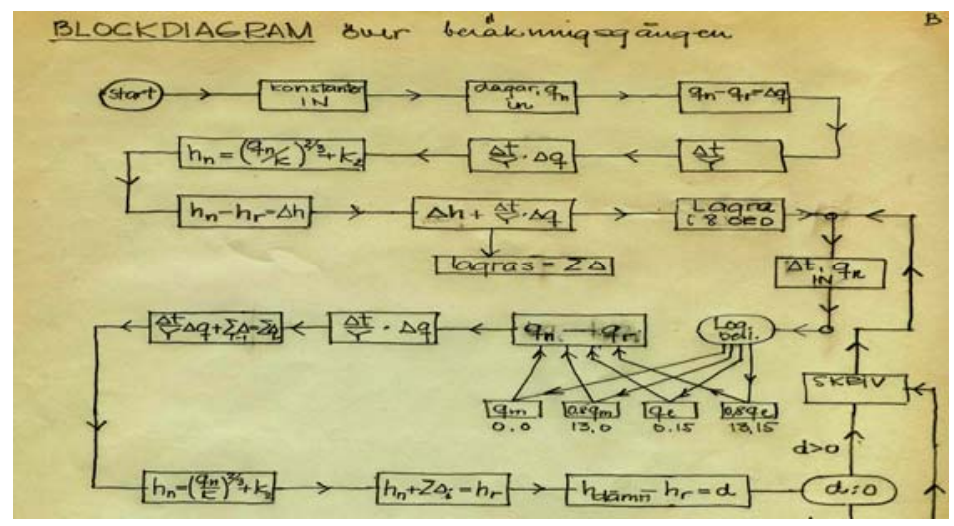

Fig. 2. A fragment of an original "problem-oriented" specification in 1957, a flowchart, showing the execution logic of a program

In its peak period, around 1960, the ADB institute's ALWAC IIIE computer was used both for numerical engineering calculations and for administrative applications, notwithstanding the computer's limited input/output speed and the lack of magnetic tape units. Companies such as Volvo, SKF, Ericsson, and the shipbuilding and shipping companies were the main customers. In this way, the ALWAC IIIE pawed the ground in western Sweden for more modern computers to come. It is interesting to note that six scientific paper presentations at NordSAM 61 in Oslo came from workers of the ADB institute.

\section{4 “Re-engineering” at KATF}

Today, Kungliga Armétygförvaltningen (KATF) has the name Försvarets Materielverk, (FMV), in English the Swedish Defence Material Administration. It deals with material and supplies for the Swedish defence. My association with KATF in 1959 was due to my military service of 13 months. One of the ALWAC machines was donated (or sold) to the consulting company, Lundins Revisionsfirma in Vallentuna, north of Stockholm. The Lundin Company received a commission from KATF to develop a large program for inventory management and control of the equipment and material (e.g. including tanks, vehicles of all types) for the Swedish Army. This consultancy job was from KATF's side managed by Nils Enquist. The program was almost completed when the Lundin Company went bankrupt. KATF had now an "almost completed" program (about 5000 instructions), no computer, and no one who 
knew about the program (except its creators Bengt-Åke Krantz and some other people then hired in at Lundins). No one at KATF knew anything about ALWAC programming. My luck was to be a young military aspirant who knew the ALWAC and ALWAC programming, and who could help them out of this situation. In 1959, KATF somehow managed to obtain the Lundin ALWAC and physically relocated it to a cellar of KATF at Gärdet in Stockholm.

My job was to "re-engineer" the 5000 instruction programme for KATF, and to make it work. What I had was machine code as shown in Figure 3. The program was not annotated in any sense. What I had to do was to reverse-program this code into a more problem-oriented description, like the flowchart in Figure 2. It was a considerable and complex re-engineering task. No other documentation existed. However, I did receive considerable help from Nils Enquist at KATF, a real enthusiast who had good knowledge about the expected logic of the inventory system ordered at Lundins. However, the way the program was developed and structured was a mystery I alone had to solve. It had taken me three months to do. In hindsight, this is probably the best way to teach somebody programming. Bengt-Åke Krantz, one of Sweden's pioneers in computers (and a mathematician) and the author of the program, was indeed a very skilful programmer. At this time all programming was a battle for space and time-you had not much of any of them. Therefore, some of Krantz's elegant, space-saving, algorithmic solutions, where a program gradually wrote over some of its own instructions, took me some time to understand and to appreciate.

The computer was "great news" at KATF. Many high-ranking military officers often visited the computer in the cellar. The computer's ability to play one or two simple games really impressed them.

The author's work at KATF also resulted in a generally usable "standard program" MIKE for matrix calculations [1]. The interpretative matrix calculation program began to appear at some of the other ALWAC installations in Sweden, mainly at the Uppsala installation. The author used it himself in doing numerical calculations (using a finite difference method for iteratively solving a system of partial differential equations) in his Licentiate Thesis [2]. They also used MIKE for stress calculations in the shipbuilding industry of Gothenburg [4].

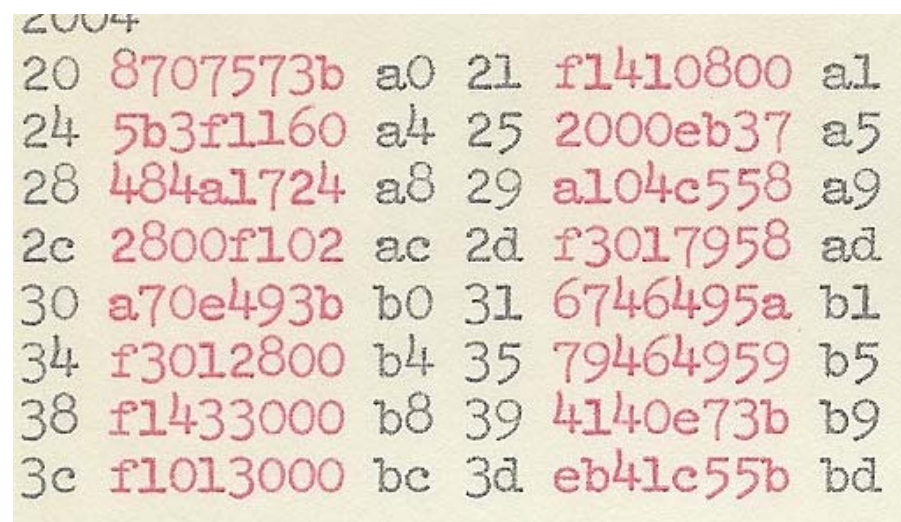

Fig. 3. A fragment of an ALWAC IIIE program in hexadecimal machine code. Black figures are addresses, red figures show the representation of the contents of a 32-bit word. 


\section{Univac in Scandinavia}

During 1960, Sperry Rand ${ }^{5}$ decided to try to enter the Nordic computer market, which at that time IBM dominated mainly through its punched-card installations. These installations gave IBM a large and loyal customer base. Other players on the Swedish market were Saab, ICL, Ferranti (with its Pegasus and Orion computers), and the French Bull computers. At that time, Sperry Rand Univac did not have any equipment installed in Sweden. All it could offer for commercial applications was the Solid State $80 / 90$, a drum-oriented computer and one of the first computers to use solid-state components. However, the Solid State 80/90 was not very powerful compared to the computers of its contemporary competitors such as the IBM 1401 and 7070 machines. Univac had, on the other hand, excellent experience with real-time computers used in United States defence, for instance the Univac 490, a commercial copy of a computer Univac Federal Systems developed for the U.S. Navy. On the positive side of Univac at this time was the pending launch of two new products: the Univac 1107 primarily for scientific applications ${ }^{6}$ and the Univac III for commercial applications. The Univac III and 1107 together with the real-time oriented 419 and 490 computers were the products of a small group of people ${ }^{7}$; they started to market them in the Nordic markets at the end of 1961. The first sales success of the group was the 1107 sales to Norsk Regnesentral (NRS). This installation as well as NRS's famous Simula software is extensively described in the book of HiNC-1 [5].

\subsection{Univac III to Götaverken}

IBM totally dominated the business data processing market in Sweden. It had more than $70 \%$ of the market. Control Data Corporation, ICL, Bull, Siemens, and "the rest" shared the remaining 30\%. We managed, however, to convince Götaverken ${ }^{8}$ (a shipyard in Gothenburg) to buy a Univac III for its administrative applications. Univac III was the last in a line of well-known computers: the Univac I and the Univac II. The Univac I was the "famous" computer delivered to the U.S. Census Bureau", Washington D.C. in 1951. The Univac III was not compatible with its predecessor Univac II. This fact probably hindered a wider sale of it. A successor of Univac III never materialized. The only Univac III sold in Sweden was the one sold to Götaverken in 1963, delivered in the fall of 1964. It had a core memory of $16 \mathrm{~K} 25$ bit words, 8 Uniservo III tape drives (speed: 133.000 characters per second), an 80-column card reader (600 cards per minute), a card punch, and a printer (1200 lines per minute). No random-access disk was included in the configuration. It used the BOSS operating system and it permitted

${ }^{5}$ Sperry Rand Corporation was formed in 1955 by the merger of Remington Rand and Sperry Gyroscope. Remington Rand had tried to enter the Nordic computer market earlier, before 1955, but failed.

${ }^{6}$ Computers for scientific applications had built-in functionality for floating-point calculations, business oriented computers had better functionality for character and string manipulation.

7 The general manager of Univac Scandinavia was Stig Wahlstam, the sales manager was Christer Svensson, and the systems and programming manager was the author.

${ }^{8}$ Actually we convinced Mr. Viklund, Götaverken's data processing manager, while some of his staff, being old IBM punched-card users, were in heavy opposition.

${ }^{9}$ Many people consider UNIVAC I the world's first commercially available computer. 
parallel execution of one main program plus a number of "spooling" programs such as cards-to-tape and tape-to-printer. It used programs written in the assembly language called UTMOST.

At that time, a computer sales contract normally involved an offer from the vendor to convert some of the customer's applications to the delivered equipment. This was also the case here. We had promised Götaverken to convert a large IBM punched-card application to Univac III. We hoped this would not take more than a couple of months. The work was free of charge for Götaverken. This sale also led to the opening of a local Univac office in Gothenburg in 1963.

The Götaverken application was a straightforward accounting routine. It included more than twenty runs on punched card equipment including sorting and collating. We designed the Univac III application having a structure very similar to the punched-card application, including a set of tape-to-tape processes. This set included a fair number of sorting operations. Therefore, the description of our application was a set of processes with defined inputs (on tape or on cards) and outputs (on tape or on printer). We described the processes by ordinary flowcharts. Records and their fields described the inputs and outputs.

\subsection{Programming Univac III in Bern}

A programming team, lead by the author, was formed in the second half of 1963 . It included new recruits ${ }^{10}$ to Univac Scandinavia. Peter Häggström and Åke Persson came from Gothenburg. Pavo Kosuta and Ralf Timell came from Stockholm. The first thing we had to do was to train the new team. The programming training as well as the application development operation was a bit complicated as no Univac III computer was available in the Nordic countries. At Kantonalbank in Bern, Switzerland, we managed to contract computer time on a Univac III. The bank's computer would be at our disposition five nights a week, from 00:00 HRS to 06:00 HRS. There was no office space available to us so all work had to be done in our hotel rooms.

The programming effort started in the fall of 1963. The application was well defined, in terms of a number of "inputs-process-outputs". It was easy to allocate well-bounded programming tasks to different programmers and then work in parallel. However, the programming took its time. We were programming in a low-level assembly language (UTMOST), which was close to machine language. The high-level language Cobol was neither reliable nor efficient enough at that time. We had also to punch the programinstruction cards ourselves. Our application consisted of more than twenty file-to-file processing programs of about 2,500 assembly level instructions each. Each program had taken two to four weeks to program and test. The whole effort to implement Götaverken's accounting system had taken about six calendar months and about twentyfour people-months of work. My estimate is our "average programming speed" was about ten instructions per person per hour, a satisfactory figure at that time.

Life as a night-shift programmer living and working in a hotel room was, at least at start, challenging and interesting. Our daily rhythm turned upside down. We slept between 08.00 and 16.00 after having breakfast at 07.00. Some programming work happened between 17.00 and 21.00. Then we had dinner before making our way to the computer centre.

${ }^{10}$ They all had university level education and some programming experience. 


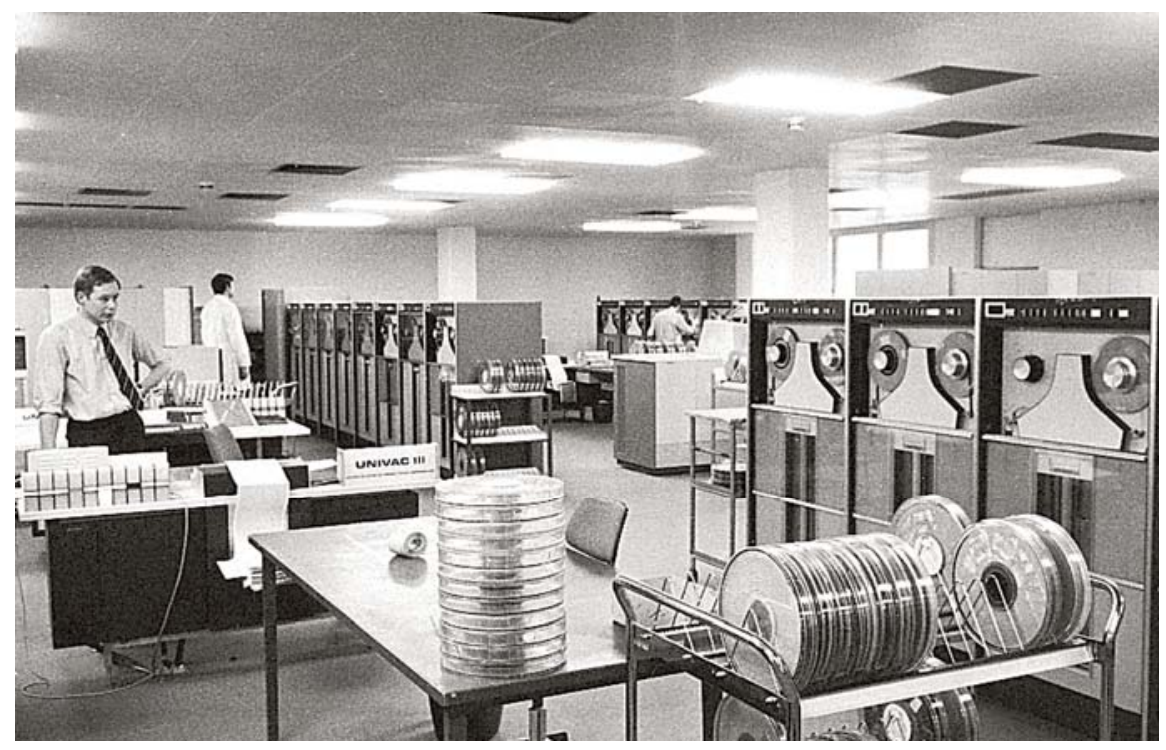

Fig. 4. A Univac III installation at Otto Group, Germany 1961 (with permission by the Otto Group). Magnetic tape reels shown in tin boxes in front.

One episode at the hotel is worth mentioning. All our data and programs were stored on large tape reels held in tin boxes. We had plenty of these tapes - more than two large suitcases. The suitcases rattled when we left the hotel shortly before midnight each night. One night the portiere could no longer refrain his curiosity about what we were doing at this time of day so he asked, "Wohin gehen Sie eigentlich meine Herren?". . Our answer was truthfully, "Zur Kantonalbank, mein Herr".

We should mention another complication of this first generation era. The card equipment ordered by Götaverken was for 80-column cards (all IBM card machines operated on 80-column cards). The Univac III at Kantonalbank used 90-column cards. This was not a problem for our programming and testing work. A bigger problem was, however, to transfer all Götaverken's master cards to Uniservo III tapes. Götaverken had about 140.000 master cards - equalling seventy boxes of 2000 cards each, weighing about 10 kilos each. The whole batch thus weighed more than 700 kilograms! This batch was flown from Gothenburg to Düsseldorf, Germany, where we were permitted to use an 80-column card based Univac III to transfer the batch to two or three tape reels. They then transferred the tapes to our test-computer at Kantonalbank to complete the accounting application. When transferring the 140.000 cards to tape in Düsseldorf, we were relatively lucky. The whole operation took less than twelve hours. Only five to ten cards "jammed", where they had to be reconstructed and re-punched. When they delivered the Univac III to Götaverken in the fall of 1964, the promised accounting system was in operation and working according to specifications.

11 "Where are you really heading gentlemen?". 


\subsection{Epilogue on Univac}

The Univac III never became a big sales success. As far as I know, Univac contracted no other Univac III to a Nordic organisation. In total, Univac delivered about 95 Univac III computer installations worldwide. A Univac computer that made some progress on the Nordic market was the powerful Univac 1107 (or its derivatives 1106 or 1108) systems. They delivered these systems to Lund University and Stadsförbun$\operatorname{det}^{12}$ in Sweden, to Finnish State Computer Centre in Helsinki, and to the Norwegian Computing Center in Trondheim. Other computers, delivered to Scandinavia include a Univac 494 to Danderyd's Hospital and a number of real-time computers $(418,494)$ to SAS for passenger and ticket management. Incidentally, Peter Häggström, one of the Univac III programming team members in Bern, became CEO of Unisys Sweden during the late 1980s.

\section{Concluding Remarks}

The above notes confirm that a structured "method" did not exist for description and development of information systems in the late 1950s and early 1960s. Such methods started to appear in the late 1960s and the early 1970s. Yet, work continued in systems development at that time occurred in a reasonably systematic and efficient way. This is probably because most "systems analysts and developers" at that time were engineers or mathematicians trained to work in a rational fashion. End-user participation in setting requirements was not common. Appendix A summarises some characteristics of systems development then and now.

\section{References}

[1] Bubenko Jr., J.A.: MIKE - ett interpretativt program för matrisräkning (MIKE - an interpretative program for matrix calculus (in Swedish)). Kungl Armetygförvaltningen, Stockholm (1960)

[2] Bubenko Jr., J.A.: Large Deflections of Rectangular Plates Solved by Finite Differences, Dept of Structural Mechanics. Chalmers Univ. of Technology, Gothenburg (1961)

[3] Bubenko Jr., J.A.: Ett system för lagerredovisning av virke. in NordSAM 61(A System for Inventory Control of Timber (in Swedish)), Oslo. preprints av sektionsföredrag (1961)

[4] Bubenko Jr., J.A., Jacobsson, Å. (eds.): Stödkrafter och Moment i Balk på Flera Stöd, Speciellt Tillämpbart på Propelleraxelledningar (Supporting Forces and Moments for Beams on Multiple Supports with a Particular Application to Propeller Axes (in Swedish)). Stiftelsen för Skeppsbyggnadsteknisk Forskning, Gothenburg (1961)

[5] Bubenko Jr., J.A., Impagliazzo, J., Sølvberg, A. (eds.): History of Nordic Computing (HiNC1). In: IFIP WG 9.7 First Working Conference on the History of Nordic Computing, Trondheim, Norway, June 16-18, 2003. Springer, New York (2005)

[6] Bubenko Jr., J.A., Jansson, C.-G., Kollerbaur, A., Ohlin, T., Yngström, L. (eds.): ICT for People. 40 Years of Academic Development in Stockholm, Department of Computer and Systems Sciences at Stockholm University and Royal Institute of Technology, Kista, Sweden, p. 426 (2006)

${ }^{12}$ The association of Swedish towns, today the association of Swedish communes. 
[7] Couger, J.D., Knapp, R.W. (eds.): System Analysis Techniques, p. 509. John Wiley \& Sons, Chichester (1974)

[8] Grivans, A., Bubenko Jr., J.A.: Snabblösning av byggnadsstatiska problem (High-speed Solving of Problems in Structural Mechanics (in Swedish)). Väg och Vattenbyggaren (3), 71-75 (1959)

[9] Suominen, J., Paju, P., Törn, A.: The Wegematic Computing Centre, 1959 - 1964. Translocal cooperation. In: Bubenko Jr., J.A., Impagliazzo, J., Sølvberg, A. (eds.) History of Nordic Computing (HiNC-1), pp. 463-486. Springer, New York (2005)

\section{Appendix A}

Some contrasting characteristics of systems development fifty years apart

\section{Systems development in the fifties}

The systems development problem was simple and mostly well defined.

The development process contains only a few phases, programming and testing being the essential ones.

Few types of "stakeholders"

The development time is long, sometimes more than a year

The developed system runs in batch mode and is used by experts only. User-friendly interfaces do not exist.

No data base access, no data base management systems in use

The computing hardware was expensive and not powerful. This generated a need to optimise the performance of a systems solution.

Computer based tools for systems development work did not exist.

Systems were developed in close physical proximity of the computer.
Systems development now

The systems development problem is often complex and not well defined. Requirements are often unclear and frequently changing.

The systems development process contains many phases starting from business analysis, requirements elicitation, etc. to systems maintenance

Many types of stakeholders

The development time is short thanks to the heavy use of standard software components

Systems are online, "real-time", and interactively used by non-experts. Interfaces are "user-friendly".

Users have through internet and advanced search engines access to a practically unlimited set of information sources

Hardware performance and cost is no longer a systems development problem. Additional processors and memory can be installed at low cost.

There is an extensive market of various software tools that support systems design as well as collaborative systems development work.

Systems development is not restricted by the distance to the computer(s) due to interactive development using high speed data links. 